\title{
A thematic issue dedicated to the giant Golden Mile Au-Te deposit, Kalgoorlie, Western Australia
}

\author{
Andreas G. Mueller ${ }^{1}$ (D) - Steffen G. Hagemann ${ }^{1}$
}

Received: 12 February 2020 / Accepted: 20 February 2020 / Published online: 9 March 2020

(C) Springer-Verlag GmbH Germany, part of Springer Nature 2020

The Kalgoorlie district in the Archean Yilgarn Craton of Western Australia comprises the Golden Mile (1767 t Au to Dec. 2018), Mt Charlotte (153 t Au) and smaller gold deposits (23 t Au combined; Keats 1987). Kalgoorlie was established in 1893, when Patrick Hannan, Thomas Flanagan and Dan Shea discovered alluvial gold. The Great Boulder Proprietary Ltd. was the first to treat sulfide ore mined below the oxide zone. The high gold grade (Table 1) sparked the sinking of hundreds of shafts on adjacent leases. Underground mining advanced to the $3670 \mathrm{ft}(-1119 \mathrm{~m})$ level of the Chaffer's shaft and lasted until 1992, when operations ceased due to the amalgamation of open cuts into the Fimiston "Super Pit" (Fig. 1).

In the first contribution to this thematic issue, Witt et al. review the subdivision of the Yilgarn Craton into a Paleo- to Mesoarchean proto-craton and the Neoarchean Eastern Goldfields Superterrane, which includes the relatively young (ca. 2.70-2.65 Ga) and juvenile Kalgoorlie-Kurnalpi Rift (KKR). Although the komatiitic rocks in the Kalgoorlie Terrane are likely plume-related, a subduction-zone tectonic setting is interpreted for the KKR, consistent with the longlived emplacement of enriched volcanic rocks and later intrusions, which cannot be explained by crustal contamination of plume-related ultramafic and mafic magmas. The Golden Mile and other "orogenic" gold deposits in the KKR are subdivided into proximal intrusion-related and distal-source types.

Mueller et al. revise the orogenic, magmatic and metamorphic evolution of the southern Kalgoorlie Terrane. Structural relations and zircon $\mathrm{U}-\mathrm{Pb}$ ages are used to correlate the

Editorial handling: B. Lehmann

Andreas G. Mueller andreasm@iinet.net.au

1 Centre for Exploration Targeting, School of Earth and Environment, The University of Western Australia, 35 Stirling Highway, Perth, W.A. 6000, Australia volcano-sedimentary successions and constrain the emplacement of porphyry intrusions and the formation of $\mathrm{Cu}-\mathrm{Au}$ skarns and mesothermal gold deposits along the Boulder Lefroy-Golden Mile transcurrent fault system. Geochemical and hornblende-apatite electron microprobe data indicate a relationship between anhydrite-bearing gold deposits such as the Golden Mile and late-orogenic, oxidized monzodioritesuite intrusions of adakitic affinity.

In Mueller, the geometry of the vast network of mineralized shear zones in the Golden Mile is illustrated on level plans and in cross-sections with emphasis on structural data from the Paringa South mine (Part 1). The steeply dipping Fimiston shear zones, centred on the D2 Golden Mile strike-slip fault, are interpreted as Riedel systems formed in the tholeiitic host rocks after D1 folding and greenschist facies metamorphism but prior to the emplacement of granodiorite dykes at ca. 2675 Ma. Wall-rock alteration and gold mineralization were broadly synchronous with the emplacement of diorite dykes at ca. $2663 \mathrm{Ma}$ and took place during alternating D2 strike-slip and D3 shortening, which generated the reverse Oroya fault system. D4 dextral strike-slip faults offset the Golden Mile lodes up to $2 \mathrm{~km}$ and control the quartz-vein ore bodies at Mt Charlotte dated at $2651 \pm 9 \mathrm{Ma}$.

Representative ore bodies (lodes) in the Paringa South mine (Part 2) are described in Mueller based on detailed mapping, petrography and whole-rock geochemistry. Fimistonstyle phengite-ankerite ore in D2 strike-slip faults replaced propylitic Golden Mile Dolerite (GMD) and contains disseminated magnetite, hematite, auriferous pyrite, minor chalcopyrite and tennantite. Oroya Au-Te ore overprints Fimiston ore in D2 faults but is the only ore in D3 reverse faults, which offset Fimiston lodes up to $50 \mathrm{~m}$. These relationships are interpreted to indicate separate hydrothermal systems. In Oroya ore, early silica-chlorite-siderite replacement (pyritearsenopyrite-sphalerite-pyrrhotite) is crosscut by silicaankerite fill (pyrite-tetrahedrite-tellurides-gold). Mass balance calculations indicate that both fluids introduced $\mathrm{CO}_{2}, \mathrm{Ca}, \mathrm{K}$, $\mathrm{Rb}$ and $\mathrm{Sr}$ but that the Oroya fluid carried higher concentrations of $\mathrm{Si}, \mathrm{Fe}, \mathrm{Ni}, \mathrm{V}$ and Te. Barren paragonite-chloritoid 
Table 1 Early production from mines, Western Lodes, Golden Mile

\begin{tabular}{|c|c|c|c|}
\hline Period & Crude ore (tonnes) & Gold (t) & Grade $(\mathrm{g} / \mathrm{t})$ \\
\hline \multicolumn{4}{|c|}{ Great Boulder Proprietary Ltd. } \\
\hline $1895-1902$ & 393,924 & 23.37 & 59.33 \\
\hline \multicolumn{4}{|c|}{ Golden Horseshoe Estates Com. } \\
\hline $1896-1907$ & $1,415,490$ & 45.60 & 32.21 \\
\hline \multicolumn{4}{|c|}{ Ivanhoe Gold Corporation Ltd. } \\
\hline 1897-1909 & $1,929,147$ & 41.94 & 21.74 \\
\hline
\end{tabular}

Data: Krusch 1903, Larcombe 1913

alteration at the southeast margin of the Golden Mile forms a thermal anomaly $\left(405-425{ }^{\circ} \mathrm{C}\right)$ in propylitic GMD (310$\left.340{ }^{\circ} \mathrm{C}\right)$.

Mueller and Muhling document wall-rock alteration and ore mineralogy in the Oroya Shoot, the main D3 ore body (>62 t Au) in the Paringa South mine (Part 3). The shoot is famous for its telluride-rich ore $(120-600 \mathrm{~g} / \mathrm{t} \mathrm{Au})$ and for its $\mathrm{V}$ rich gangue including nolanite, muscovite, chlorite and tourmaline. Chlorite and arsenopyrite thermometry indicate rapid fluid cooling from $450-400^{\circ} \mathrm{C}$ to $340{ }^{\circ} \mathrm{C}$ during Stage 1 deposition of silica, chlorite, siderite, dendritic pyrite, chalcopyrite and sphalerite. Stage 2 quartz-ankerite breccia ore is characterized by montbrayite, tellurantimony and free gold. Altaite-tellurium myrmekites are interpreted as melt droplets deposited at $>400{ }^{\circ} \mathrm{C}$. Late covellite and digenite were deposited at low tellurium but high sulfur fugacity. Mass balance calculations based on Oroya ore, and carbon-oxygen isotope data from dolomite in a late-mineralization kersantite dyke, implicate the local monzodiorite plutons as the fluid source.

Mueller et al. constrain the PTX conditions of gold deposition in the ore bodies described in Part 2 of the Paringa South series. The input fluids $\left(\mathrm{PT}=300 \mathrm{MPa}, 420 \pm 30^{\circ} \mathrm{C}\right)$ cooled to the ambient temperature at $10 \mathrm{~km}$ depth $\left(250-300{ }^{\circ} \mathrm{C}\right)$. Fimiston refractory ore $(7 \mathrm{~g} / \mathrm{t} \mathrm{Au})$ formed during the replacement of propylitic chlorite by ankerite, magnetite and pyrite, the latter enclosing micron- to nano-sized gold and $\mathrm{Au}-\mathrm{Ag}$ tellurides. High-grade Oroya ore (30-120 g/t Au) replaced previously altered ankerite-rich wall rock. Rapid cooling, an acidic fluid $\mathrm{pH}$ and the retrograde solubility of ankerite facilitated Stage 1 chalcedony-pyrite replacement. Locally, the fluid was reduced by trapped organic methane. In Oroya Stage 2 pyrite-telluride \pm magnetite ore, grains of tellurantimony,

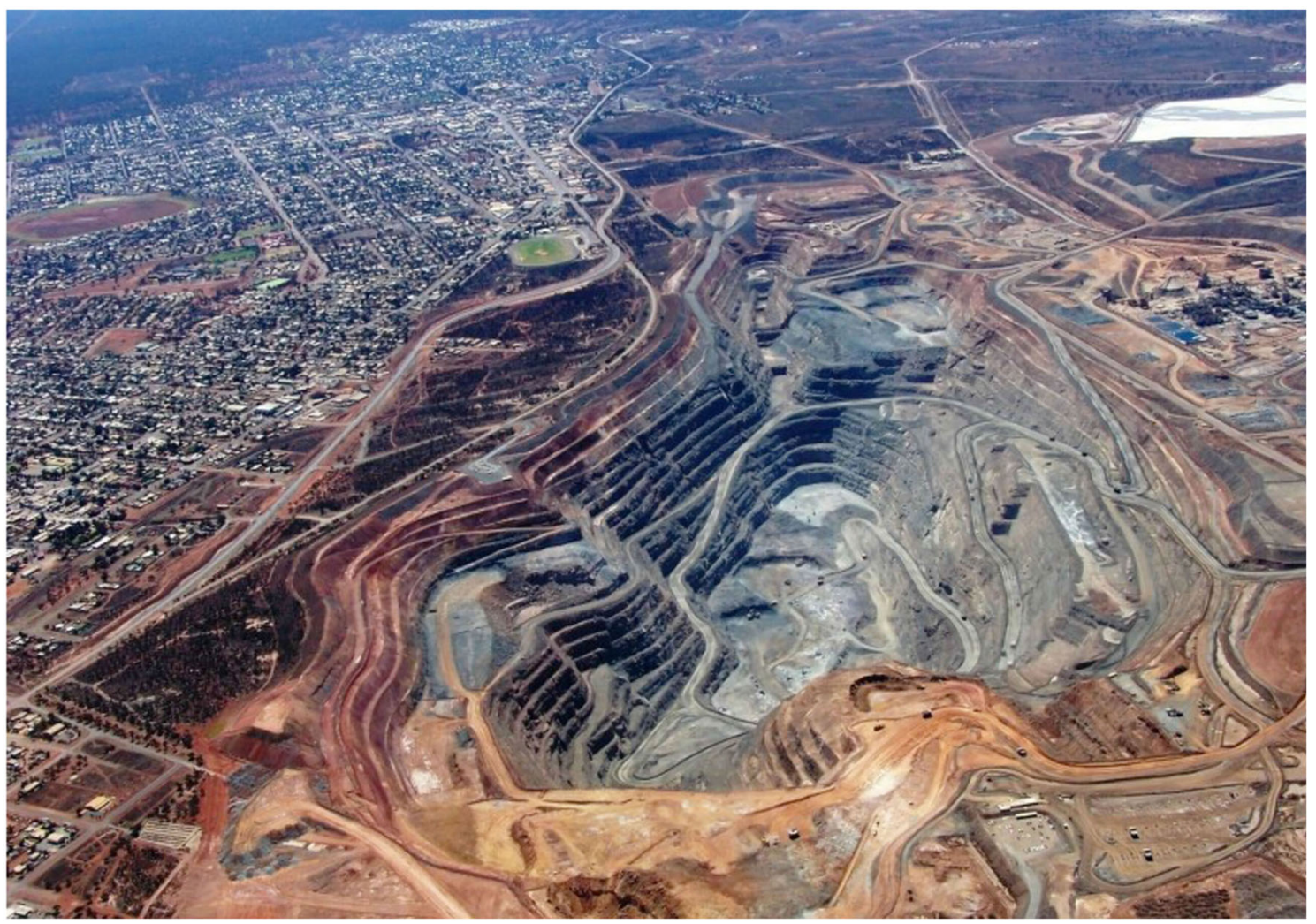

Fig. 1 Looking northwest into the Fimiston "Super Pit" at Kalgoorlie, Western Australia, courtesy of Kalgoorlie Consolidated Gold Mines (website download 2006). In June 2019, the Super Pit was $4.0 \mathrm{~km}$ long, $1.5 \mathrm{~km}$ wide and up to $620 \mathrm{~m}$ deep. The sulfide ore milled in 2018 amounted to 13.2 million metric tons at $1.78 \mathrm{~g} / \mathrm{t} \mathrm{Au}$ head grade including 0.904 million tons at $2.57 \mathrm{~g} / \mathrm{t} \mathrm{Au}$ from the Mt Charlotte underground mine. Gold recovery by cyanide leach after ultra-fine grinding of the pyrite flotation concentrate was $82-83 \%$ (Q4 mine statistics 2018; barrick.com). Dark green propylitic Golden Mile Dolerite is exposed in the southwest wall and central part of the open pit. Light brown Paringa Basalt, altered pervasively to a pre-sulfide sericite-quartz-ankerite assemblage in a broad contact zone, forms the northeast wall of the open pit. Dark red-brown laterite soil extends to about $50 \mathrm{~m}$ depth 
altaite, calaverite, petzite and montbrayite were deposited at about $400{ }^{\circ} \mathrm{C}$. As fluid temperature and tellurium fugacity declined, native gold, krennerite, coloradoite, melonite, sylvanite and hessite crystallized. Genetic similarities between the Golden Mile and the Miocene Porgera gold deposit are discussed.

Godefroy-Rodriguez et al. present multiple sulfur isotope analyses $\left(\delta^{34} S, \Delta^{33} S, \Delta^{36} S\right)$ obtained by secondary ion mass spectrometry (SIMS) in pyrite from the Kapai Slate black shale marker bed, and from Fimiston, Oroya and Mt Charlotte hydrothermal gold ore. The results reveal a very large spread in $\delta^{34} \mathrm{~S}\left(-12.6\right.$ to $+23.5 \%$ ) and $\Delta^{33} S$ values $(-1.0$ to $+1.1 \%$ ) , caused by oxidized (Fimiston) versus reduced hydrothermal conditions (Oroya, Mt Charlotte) in the case of $\delta^{34} S$ and by the mixing of crustal- and mantle-derived sulfur in the case of $\Delta^{33} S$. In $\Delta^{33} S-\Delta^{36} S$ space, a regression line of $-0.75 \pm 0.34$ $\left(r^{2}=0.53\right)$ is fitted to all data, different from the array defined by Archean sedimentary rocks ( -0.9 to -1.5 ; Johnston 2011).

Finally, Godefroy-Rodriguez et al. complement the sulfur isotope data with pyrite trace element analyses using laser ablation inductively coupled plasma mass spectrometry (LAICP-MS). Syngenetic/diagenetic pyrite from the Kapai Slate is barren of gold consistent with whole-rock assays of $\leq 0.06 \mathrm{~g} / \mathrm{t}$. In hydrothermal pyrite, the $75-\mu \mathrm{m}$ ablation spots detected AuAg-Te inclusions and lattice-bound elements (e.g. Ni, Co, As). Linear mixed effects (LME) modelling of the analytical data indicates systematic differences between pyrites co-existing with oxidized and reduced mineral assemblages in Fimiston-, Oroya- and Charlotte-style ore. In combination with metallurgical data, the results suggest that nano-sized inclusions rather than lattice-bound gold are responsible for the low recovery (82-83\%) in the Fimiston mill.

\section{A short review of previous research}

The discovery of tellurides in Golden Mile ore (Holroyd 1897) stimulated research on ore and gangue mineralogy (Krusch 1901; Lindgren 1906), enhanced and summarized in Simpson and Gibson (1912) and complemented by the studies of Stillwell (1931), Golding (1978) and Shackleton et al. (2003). Fieldwork by the Geological Survey of Western Australia (GSWA) progressed from mining lease mapping on basic geology (Maitland and Campbell 1902) to the documentation of outcrops and mine workings throughout the Kalgoorlie district (Simpson and Gibson 1912; Feldtmann and Farquharson 1913; Feldtmann 1916). The fourth bulletin of the Kalgoorlie series by Feldtmann (about 1928) was never published in print but is available as a free GSWA download (www.dmp.wa.gov.au). Some of his Golden Mile level plans and cross-sections became part of the study of Stillwell (1929), still a valuable source of structural and petrographic information today.
Privately funded studies include those of Krusch (1903), MacLaren and Thomson (1913), Thomson (1913) and Larcombe (1913). The geological maps and sections prepared by MacLaren, "illuminating to those privileged to see them" (Stillwell 1929), remained confidential and only the petrographic work of Thomson was published. Gustafson and Miller (1937) recognized isoclinal folding in the Kalgoorlie district but concluded that the geometry of the Golden Mile lode system ruled out a relationship to folding. They were also the first to infer a granitoid batholith at depth as the source of the porphyry dykes and hydrothermal fluid.

After World War II, structural studies by Finucane (1948), Tomich (1952) and Wells (1964) enhanced our understanding of the Golden Mile. District-scale mapping by Western Mining Corporation (Campbell 1953; Woodall 1965; Travis et al. 1971; Clout et al. 1990) and GSWA geologists (Keats 1987) outlined a complex system of faults transecting the regional folds. The crosscutting relationships and fault geometries were reinterpreted by Mueller et al. (1988), who related the Golden Mile shear zones to sinistral strike-slip on the bounding faults. They also recognized that the Mt Charlotte quartz-vein ore bodies were structurally younger than the Golden Mile deposit. The combination of company and GSWA mapping led to the delineation of the gold-rich Boulder-Lefroy fault system extending more than $100 \mathrm{~km}$ in strike (Mueller and Harris 1987; Swager 1989; Swager et al. 1995). The crustal-scale nature of the Boulder-Lefroy and other regional faults became instrumental in the development of the metamorphic hydrothermal model for Archean gold deposits (Phillips 1986; Groves 1993). Aspects of this and other genetic models are reviewed in Hagemann and Cassidy (2000) and in Bateman and Hagemann (2004). The results presented in this thematic issue suggest that the metamorphic fluid model proposed for "orogenic" gold deposits requires modification. The anhydritebearing Golden Mile Au-Te deposit may be "orogenic" due to its location in a fold belt but formed by the superposition of two intrusion-related hydrothermal systems: Fimiston and Oroya.

Acknowledgements Both guest editors acknowledge the support of Bernd Lehmann and the manuscript referees, whose input led to substantial improvements: Andrea Agangi, Louis Cabri, David Cooke, Matthias Cornelius, David Craw, Benoit Dubé, Paul Duuring, Max Frenzel, Sue Golding, Chris Hesford, David Huston, Gawen Jenkins, Stephen Kesler, Jochen Kolb, Robert Linnen, Janet Muhling, Juhani Ojala, Caroline Perring, Martin Reich, John Ridley, James Saunders, Gerard Tripp, Walter Witt, Derek Wyman and Jiř́ Zachariáš.

\section{References}

Bateman R, Hagemann S (2004) Gold mineralization throughout about $45 \mathrm{Ma}$ of Archaean orogenesis: protracted flux of gold in the Golden Mile, Yilgarn craton, Western Australia. Miner Deposita 39:536559 
Campbell JD (1953) The structure of the Kalgoorlie Goldfield. In: Edwards AB (ed) Geology of Australian ore deposits. 5th Empire Min Metall Congress, Melbourne, pp 79-93

Clout JMF, Cleghorn JH, Eaton PC (1990) Geology of the Kalgoorlie goldfield. In: Hughes FE (ed) Geology of the mineral deposits of Australia and Papua New Guinea. Melbourne, Australasian Inst Min Metall Monograph 14, pp 411-431

Feldtmann FR, Farquharson RA (1913) Contributions to the study of the geology and ore deposits of Kalgoorlie, East Coolgardie Goldfield, part 2. Geol Surv West Australia Bull 51, 85 pp

Feldtmann FR (1916) Contributions to the study of the geology and ore deposits of Kalgoorlie, East Coolgardie Goldfield, part 3. Geol Surv West Australia Bull 69, $152 \mathrm{pp}$

Feldtmann FR (1928) Contributions to the study of the geology and ore deposits of Kalgoorlie, East Coolgardie Goldfield, Part 4: the geology and ore deposits of the western portion of the Boulder Belt. Geol Surv West Australia Bull 69A, 297 pp (unfinished typed manuscript)

Finucane KJ (1948) Ore distribution and lode structures in the Kalgoorlie Goldfield. Proc Aust Inst Min Metall 148:111-129

Golding LY (1978) Mineralogy, geochemistry and origin of the Kalgoorlie gold deposits, Western Australia. Dissertation, The University of Melbourne, Melbourne, $402 \mathrm{pp}$

Groves DI (1993) The crustal continuum model for late-Archaean lodegold deposits of the Yilgarn Block, Western Australia. Miner Deposita 28:366-374

Gustafson JK, Miller FS (1937) Kalgoorlie geology re-interpreted. Proc Aust Inst Min Metall 106:93-125 and 107:239-251

Hagemann SG, Cassidy KF (2000) Archean orogenic lode gold deposits. SEG Rev 13:9-68

Holroyd AG (1897) The discovery and occurrence of telluride of gold upon the Kalgoorlie Goldfield, East Coolgardie. Trans Aust Inst Min Eng 4:186-193

Johnston DT (2011) Multiple sulfur isotopes and the evolution of Earth's surface sulfur cycle. Earth Sci Rev 106:161-183

Keats W (1987) Regional geology of the Kalgoorlie-Boulder gold-mining district. Geol Surv West Australia Rep 21, 44 pp

Krusch P (1901) Die Tellurerze Westaustraliens. Zeitschrift praktische Geologie 9:211-217

Krusch P (1903) Beitrag zur Kenntnis der nutzbaren Lagerstätten Westaustraliens. Zeitschrift für praktische Geologie 11:321-331, 369-389

Larcombe COG (1913) The geology of Kalgoorlie, Western Australia, with special reference to the ore deposits. Australasian Inst Min Eng, Melbourne, Monograph $315 \mathrm{pp}$

Lindgren W (1906) Metasomatic processes in the gold deposits of Western Australia. Econ Geol 1:530-544
MacLaren M, Thomson JA (1913) Geology of the Kalgoorlie Goldfield, Parts 1-5. Mining and Scientific Press 107:45-48, 95-99, 187-190, 228-232, 374-379

Mueller AG, Harris LB (1987) An application of wrench tectonic models to mineralized structures in the Golden Mile district, Kalgoorlie, Western Australia. In: Ho SE, Groves DI (eds) Recent advances in understanding Precambrian gold deposits. University of Western Australia, Geology Department and University Extension, Publ 11, pp $97-107$

Mueller AG, Harris LB, Lungan A (1988) Structural control of greenstone-hosted gold mineralization by transcurrent shearing - a new interpretation of the Kalgoorlie mining district, Western Australia. Ore Geol Rev 3:359-387

Phillips GN (1986) Geology and alteration in the Golden Mile, Kalgoorlie. Econ Geol 81:779-808

Shackleton JM, Spry PG, Bateman R (2003) Telluride mineralogy of the Golden Mile deposit, Kalgoorlie, Western Australia. Can Mineral 41:1503-1524

Simpson ES, Gibson CG (1912) The geology and ore deposits of Kalgoorlie, East Coolgardie Goldfield, Part 1. Geol Surv West Australia Bull 42, 198 pp

Stillwell FL (1929) Geology and ore deposits of the Boulder Belt, Kalgoorlie. Geol Surv West Australia Bull 94, 110 pp

Stillwell FL (1931) The occurrence of telluride minerals at Kalgoorlie. Proc Aust Inst Min Metall 84:115-190

Swager CP (1989) Structure of Kalgoorlie greenstones - regional deformation history and implications for the structural setting of the Golden Mile gold deposits. Geol Surv West Australia Rep 25:59-84

Swager CP, Griffin TJ, Witt WK, Wyche S, Ahmat AL, Hunter WM, McGoldrick PJ (1995) Geology of the Archaean Kalgoorlie terrane an explanatory note. Geol Surv West Australia Rep 48, 26 pp

Thomson JA (1913) On the petrology of the Kalgoorlie Goldfield, Western Australia. Quart J Geol Soc London 69:621-677

Tomich SA (1952) Some structural aspects of Kalgoorlie geology. Proc Aust Inst Min Metall 164/165:45-76

Travis GA, Woodall R, Bartram GD (1971) The geology of the Kalgoorlie Goldfield. In: Glover JE (ed) Symposium on Archaean Rocks. Geol Soc Australia Publ 3, pp 175-190

Wells AA (1964) Western lode structures and southwards extensions of the Boulder mining belt. Proc Aust Inst Min Metall 211:181-192

Woodall R (1965) Structure of the Kalgoorlie goldfield. $8^{\text {th }}$ Commonwealth Min Metall Congress, Melbourne, pp 71-79

Publisher's note Springer Nature remains neutral with regard to jurisdictional claims in published maps and institutional affiliations. 